Publishing Company. Contributions may be written in English, French or German, but the abstract must always be in English. The text and diagrams are clear and well printed and the standard of the articles conforms to that of the better scientific journals. However, one article from the Franklin Institute is an abbreviated version of a chapter of a book shortly to be published, and the units used in several of the articles reflect whether the authors are engineers or scientists.

\section{A Bibliography of Dictionaries}

A COMPREHENSIVE bibliography, processed by punchedcard, machine-sorting, and photo-offset techniques, in which are listed more than 2,800 bilingual and polyglot dictionaries, glossaries and encyclopaedias published during 1952-63, has been compiled by T. W. Marton of the National Bureau of Standards, U.S. Department of Commerce (Miscellaneous Publication No. 258. Washington, D.C. : Government Printing Office, 1964. 1.25 dollars). The entries are subdivided into 49 subject classes covering the physical sciences, engineering and technology, and are listed in alphabetical order by language. Within each language group the entries are arranged alphabetically by author or title, and consist of the names of the individual or corporate authors, the original title of the work, an abbreviated translation of foreign titles, the imprint, the Library of Congress card number, and the approximate number of terms contained in the work. Forty-seven foreign languages are represented in the bibliography. Detailed indexes, by author, language and subject, complete the publication, which by its large coverage will be of great value to scientists and engineers, abstractcrs, technical information officors, librarians and translators.

\section{A Directory of Information Resources}

A DIRECTORY has been published by the National Referral Center for Science and Technology at the U.S. Library of Congress. The book, of 356 pages, is entitled A Directory of Information Resources in the United States : Physical Sciences, Biological Sciences, Engineering (available from Superintendent of Documents, Government Printing Office, Washington, D.C. 20402, 2.25 dollars). The volume contains narrative descriptions of the subject specialization, information services, and publications of some 1,100 organizations and institutions throughout the United States. Professional societies, academic research groups, industrial firms, Government offices and technical libraries are included. The National Referral Center, supported by funds from the National Science Foundation, is now preparing a similar volume in the social sciences, based on data gathered in a special survey by the Bureau of Applied Social Research at Columbia University. Plans are being made for specialized listings to meet specific requirements in selected areas.

\section{Dual Effect of Boron and Manganese on Growth of Raspberries}

Dr. C. L. Whitrues, Campbell House, Mauchline, Ayrshire, Scotland, has written to the Editor emphasizing the necessity of estimating the effects of micro-elements on plant growth more comprehensively than is frequently done. In a long-term experiment with raspberries (Burnet Holme Seedling) on ground well supplied with nitrogen, phosphorus and potassium, he failed to obtain any enhancement of vigour from applications of boron alone, even though leaves from treated plants had ten times the boron content of controls. Treatment with manganese borate ( $1 \mathrm{lb}$. per 20 -yd. row, giving 20 p.p.m. boron and 25 p.p.m. manganese in the soil), however, gave spectacular increase of growth and fruitfulness. The variety Burnet Holme is apt to decline in vigour, even with adequate soil fertility, showing increasing amounts of 'die-back' and virus-like symptoms in the process. Dual application of boron and manganese arrested the decline and rapidly restored the vigour, eliminating also the die-back and the virus-like symptoms. Apical buds of untreated plants, moreover, became dormant in August (a condition recog. nized by tea planters and called 'banjhi'). Application of manganese borate broke this dormancy, and within $72 \mathrm{~h}$ after treatment the shoot had begun to extend. It is possible, indeed likely, that response to manganese borate will vary on different soils, but the necessity for integrated investigation of micro-nutrients of plants is an important consideration arising from this work.

\section{The Institute of Physics and the Physical Society:} Appointments and Awards for 1965

THE Council of the Institute and Society has made the following appointments and awards for 1965; the presentations will be made in London at the annual dinner of the Institute and Society on May 4: Guthrie Lecturer, Dr. J. B. Adams, director of the Culham Laboratory of the U.K. Atomic Energy Authority; Thomas Young Medal and Prize, to Prof. A. Maréchal of the University of Paris and the Institut d'Optique, Paris, for his distinguished work in many fields of optics; Duddell Medal and Prize, to Dr. H. A. Gebbie of the National Physical Laboratory, for his pioneering work in interference spectroscopy in the infra-red; Charles Chree Medal and Prize, to Prof. B. J. Mason of the Imperial College of Science and Technology, for his work in atmospheric physics; Charles Vernon Boys Prize, to Dr. A. Howie and Dr. M. J. Whelan of the University of Cambridge, for their studies of lattice defects in crystals by electron microscopy.

\section{Travelling Research Fellowships to Denmark and Sweden, 1965-1966}

Applications are invited for the Carlsberg-Wellcome and Wellcome-Swedish travelling research fellowships, 1965-66. The object of these is to encourage working visits, on an exchange basis, between Danish and British, and Swedish and British, investigators in any branches of the natural sciences which have a bearing on human and animal medicine. One of each fellowship is awarded annually to a graduate from the United Kingdom for a year's work in the exchange country, and one Swedish and one Danish candidate annually may work in the United Kingdom. The stipend may range from $£ 1,000$ to $£ 2,000$ per annum; travelling and some ineidental expenses are provided in addition. The Carlsberg-Wellcome fellowships are arranged with the Carlsberg Foundation in Copenhagen; the Wellcome Swedish fellowships are provided jointly by the Medical Research Council of Sweden and the Wellcome Trust. Candidates in the United Kingdom can obtain further information from the Scientific Secretary, the Wellcome Trust, 52 Queen Anne Street, London, W.1. Completed applications must be submitted by April 9, 1965.

\section{Physics Exhibition}

The Physics Exhibition, 1965, will be held in the Manchester College of Science and Technology during April 5-8. The Exhibition endeavours to show recent advances in physics and its applications and in methods of teaching physics. Emphasis is placed on new scientific instruments and apparatus and their possible uses for improving productivity. During the Exhibition, the following lectures will be given: physical instruments in biophysical and biological researeh (Dr. A. Elliott, King's College, London); instrumentation problems in computer control systems (J. L. W. Churchill, A.E.I. Automation, Ltd.); instrumentation in process and product control in the textile industry (Dr. D. W. Hill, Cotton, Silk and Man-made Fibres Research Association). Further information and tickets can be obtained from the Secretary, Institute of Physics and the Physical Society, 47 Belgrave Square, London, S.W.1. 